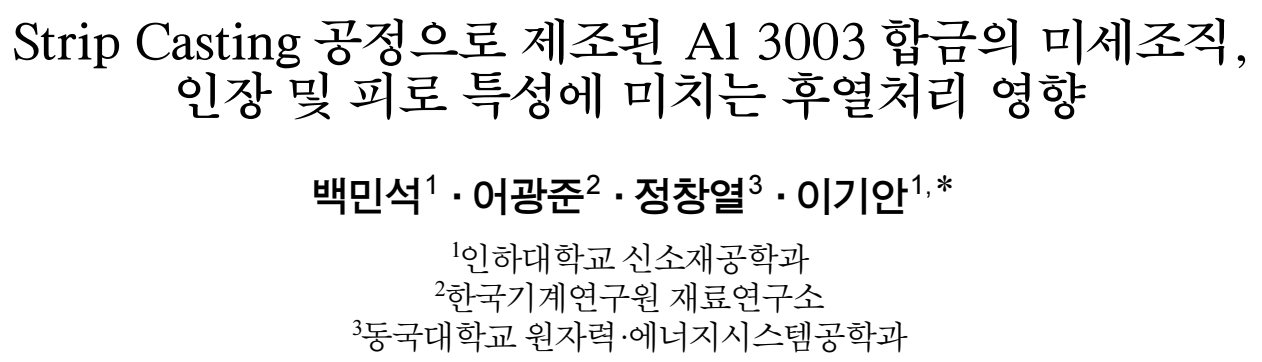

\title{
Effect of Post Heat-Treatment on the Microstructure, Tensile and Fatigue Properties of Al 3003 Alloy Manufactured by Strip Casting Process
}

\author{
Min-Seok Baek ${ }^{1}$, Kwangjun Euh ${ }^{2}$, Chang-Yeol Jeong ${ }^{3}$, and Kee-Ahn Lee ${ }^{1, *}$ \\ ${ }^{1}$ Depertment of Materials Science and Engineering, Inha University, Incheon 22212, Republic of Korea \\ ${ }^{2}$ Korea Institute of Materials Science, Changwon 51508, Republic of Korea \\ ${ }^{3}$ Department of Nuclear and Energy System Engineering, Dongguk University, Gyeongju 38066, Republic of Korea
}

\begin{abstract}
Al 3003 alloy was manufactured by strip casting process, and the effect of post heat-treatment on tensile and fatigue properties was investigated. The strip cast $\mathrm{Al} 300$ alloy exhibited a unique globular shaped rapid-cooled solidification structure, and the microstructural characteristic remained after heat-treatment. Asstrip cast (F) and heat-treated (O) alloys were commonly composed of $\mathrm{Al}$ matrix and strengthening phases such as $\mathrm{Al}_{6}(\mathrm{Mn}, \mathrm{Fe}), \alpha-\mathrm{Al}(\mathrm{Mn}, \mathrm{Fe}) \mathrm{Si}$. In the phase analysis and Factsage simulation result, $\mathrm{Al}_{6}(\mathrm{Mn}, \mathrm{Fe})$ fraction increased while $\alpha-\mathrm{Al}(\mathrm{Mn}, \mathrm{Fe}) \mathrm{Si}$ fraction decreased after heat-treatment. Strengthening phases were more uniformly and finely distributed in the case of $\mathrm{O}$ alloy, than $\mathrm{F}$ alloy. In the Vickers hardness results, $\mathrm{F}$ alloy (measured $59.7 \mathrm{Hv}$ ) showed higher hardness than $\mathrm{O}$ alloy (measured $53.4 \mathrm{Hv}$ ). The yield strengths (YS) and ultimate tensile strengths (UTS) measured 124.8 MPa and 166.4 MPa (F alloy), and 111.2 MPa and 167.2 MPa (O alloy), respectively. F alloy exhibited superior YS compared to $\mathrm{O}$ alloy, while UTSs were similar in both alloys. For elongation, the $\mathrm{F}$ alloy (19.6\%) had a lower value than the $\mathrm{O}$ alloy (23.0\%). High cycle fatigue tests were performed at room temperature under a stress ratio (R) of 0.1 and frequency $(\mathrm{F})$ of $10 \mathrm{~Hz}$. The $\mathrm{F}$ alloy exhibited higher fatigue than the $\mathrm{O}$ alloy under all cyclic stress conditions. However, the deviation in the fatigue property of the $\mathrm{F}$ alloy was relatively broader than the $\mathrm{O}$ alloy. Tensile and fatigue fracture surfaces were examined, and the tensile and fatigue deformation mechanisms of the strip cast $\mathrm{Al} 3003$ alloy were also discussed.
\end{abstract}

(Received September 18, 2019; Accepted December 16, 2019)

Keywords: strip casting, $\mathrm{Al} 3003, \mathrm{Al}-\mathrm{Mn}$ alloy, tensile property, high cycle fatigue, heat treatment

\begin{abstract}
1. 서 론
- 백민석: 박사과정, 어광준: 연구원, 정창열·이기안: 교수

*Corresponding Author: Kee-Ahn Lee

[Tel: +82-32-860-7532, E-mail: keeahn@inha.ac.kr]

Copyright (c) The Korean Institute of Metals and Materials
\end{abstract}

히터 튜브, 증발기, 저장탱크, 자동차 열 교환기용 등에 사용되는 $\mathrm{Al}-\mathrm{Mn}$ 계 합금은 $\mathrm{Mn}$ 원소를 첨가함으로 인해 고용 강화(solid solution strengthening) 및 미세 석출 강 화 (precipitation strengthening) 효과를 유도할 수 있다.
또한 이 합금은 낮은 밀도의 경량 소재로 충분한 강도 및 우수한 비강도, 내식성, 열전도도, 성형성 등의 장점을 가 진다 [1,2]. 현재까지, $\mathrm{Al} 3 \mathrm{xxx}$ 계 합금은 주로 direct chill (DC) 주조 공정을 이용하여 제조되어 왔으며, 이에 $\mathrm{DC}$ 주조로 제조된 소재의 미세조직과 기계적 특성에 대한 연구가 보고된 바 있다 [2].

Strip casting 공정은 $\mathrm{DC}$ 주조 공정에 반해 성형 (forming), 압연(rolling) 등 다른 중간 공정 없이 금속 용 탕에서 바로 판재가 제조 가능한 공정이다 [3]. 이러한 strip casting 공정은 크게 단롤(single roll), 쌍롤(twin 
roll) 공정들로 나눌 수 있다. 이와 함께 strip casting 공 정의 장점으로는 생산 속도 향상, 공정 비용의 감소, 급냉 응고 조직에 기인한 기계적 특성 향상 등이 존재하며, 상 기 공정을 $\mathrm{Al}$ 합금 제조에 적용시키고자 하는 시도들이 있었다 [3-5].

Strip casting 공정으로 제조된 구조용 소재가 사용되기 위해서는 일정 수준 이상의 두께를 가져야한다. 하지만 판 재 두께가 두꺼울 경우 strip casting 공정 특성상 빠른 냉 각 속도에 기인하여 불균일한 미세조직 (상 크기 및 분포 등)을 나타낼 수 있다. 또한 소재 내부의 석출상들은 혼재 된 형태로 존재하며, 기계적 특성 저하가 야기될 수 있다 [6,7]. 따라서 이러한 문제점들을 해결하기 위한 후 열처리 의 중요성이 높다.

현재까지 $\mathrm{Al}-\mathrm{Mn}$ 계 합금에서 $\mathrm{DC}$ 주조 등 기존 공정으 로 제조된 소재에 대하여 후 열처리를 통한 상 변화, 석출 물 균질화 등의 연구가 진행되었다 [8,9]. 또한 DC 주조 $\mathrm{Al}-\mathrm{Mn}$ 계 합금에서 후 열처리에 따른 석출상들의 분포 및 크기 변화에 대해서도 보고된 바 있다 [8-11]. 후 열처리 이후 Chinese script 형상의 $\mathrm{Al}_{6}(\mathrm{Mn}, \mathrm{Fe})$ 상들은 침상 (needle) 형태로 바뀌거나 고루 분산된다고 언급되었다. 그 외 일부 strip casting 공정으로 제조된 금속 소재에 대해 서도 기계적 특성에 미치는 후 열처리 영향 [12-14], 균질 화 영향 [15]에 대해 조사된 바 있지만 미세조직과 연계한 거동 해석은 미흡한 실정이다. 이에 strip casting 공정으로 제조된 $\mathrm{Al}-\mathrm{Mn}$ 계 합금의 미세조직 및 물성에 미치는 후 열처리 영향에 대한 연구도 필요하지만 현재까지 거의 보 고된 바 없다 [10]. 특히 후 열처리에 따른 피로 물성 및 변형 거동에 대한 연구는 전무한 실정이다.

본 연구에서는 strip casting 공정으로 제조된 Al 3003 합 금의 인장 및 피로 특성에 미치는 후 열처리 영향에 대해 조 사하였다. 또한 열처리 전, 후의 미세조직 변화 그리고 인장 및 피로 파면 관찰을 통하여 변형 거동과 미세조직과의 상관 관계 및 미세 변형 기구에 대해서도 제시하고자 하였다.

\section{2. 실험 방법}

본 연구에서는 strip casting 공정 중 하나인 twin roll casting(TRC)을 이용하여 두께 $8 \mathrm{~mm}$, 폭 $400 \mathrm{~mm}$ 의 판재 를 제조하였다. 이 때 주조 속도 $800 \sim 850 \mathrm{~mm} / \mathrm{min}$., 출 탕 온도 $700 \sim 720^{\circ} \mathrm{C}$, 롤 온도 $100 \sim 120^{\circ} \mathrm{C}$ 의 공정 조건 을 사용하였다. 상기 strip casting 공정 조건은 최적의 공 정 조건 도출 실험들을 통해 얻은 조건이다. 제조된 소재 의 미세조직 제어를 위해 어닐링(annealing, O) 열처리를
수행하였다. 열처리 조건은 $450{ }^{\circ} \mathrm{C}$ 에서 6 시간 동안 유지한 후 공냉(air cooling)하였다.

열처리 전, 후 소재의 상 분석을 위하여 Ultima IV 장 비를 이용한 X-ray diffraction(XRD) 분석과 EPMA-1600 장비를 사용한 electron probe X-ray microanalyzer (EPMA) 분석을 수행하였다. XRD 및 EPMA 분석을 위 해 먼저 준비된 시편을 \#400 \#4000까지 연마(polishing)하 였고, 이후 $1 \mu \mathrm{m}$ 다이아몬드 페이스트(paste)를 이용하여 추가 경면 연마를 수행하였다. 또한 열처리 전, 후의 상 및 결정립 등의 미세조직 변화를 관찰하기 위해 편광 현미 경, field emission-scanning electron microscopy(FESEM, TESCAN; MYRA III), electron back-scattered diffraction(EBSD, OXFORD-MYRA III), transmission electron microscopy(TEM, JEOL; JEM-2010) 장비를 이 용하여 관찰, 분석하였다. 이와 함께 Factsage(DB-Factsage 6.4/FT lite) 프로그램을 이용하여 생성될 수 있는 열역학 기반의 상 모사(phase simulation)도 수행하였다. FE-SEM, $\mathrm{EBSD}$ 미세조직 관찰을 위해 시편 준비 후 폴리셔 (polisher)로 \#400 \#4000까지 연마한 후, $1 \mu \mathrm{m}$ 다이아몬드 페이스트를 이용하여 경면 연마를 수행하였다. FE-SEM 미 세조직을 관찰할 시편의 에칭액(etchant)은 $50 \mathrm{ml} \mathrm{H} \mathrm{H}_{2} \mathrm{O}+$ $25 \mathrm{ml} \mathrm{HCl}+15 \mathrm{ml} \mathrm{NaNO}+10 \mathrm{ml} \mathrm{HF}$ 를 사용하였으며, 수 초 동안 에칭(etching)을 수행하였다.

제조된 소재의 기계적 특성을 알아보고자 먼저 $\mathrm{Al} 3003$ $\mathrm{F}$ (as-fabricated) 소재와 $\mathrm{O}$ (annealing) 소재의 경도 및 인장 시험을 수행하였다. 경도 시험은 각 시편당 12 번씩, 인장 시험은 3번씩 수행하였다. 인장 시험 수행 시, 정확한 변 형량을 측정하기 위해 extensometer를 장착하여 진행하였 다. 고주기 피로 시험은 상온에서 피로 응력 주파수 (fatigue stress frequency) $=10 \mathrm{~Hz}, \sim 10^{7}$ 싸이클을 피로 파단 조건(피로한도)으로 잡았으며 각 피로 응력 조건당 3 회씩 반복 수행하였다. 또한 응력 비 $(\mathrm{R})$ 는 0.1 값을 사용 하였다. 이는 응력 비가 -1 (인장-압축)으로 피로 시험이 진행되었을 때, 피로 파면이 손상될 우려가 있기 때문이다. 인장 및 고주기 피로 파단면을 관찰/분석하기 위하여 scanning electron microscope(SEM, TESCAN; VEGA II LMU)장비를 사용하였다.

\section{3. 결과 및 토론}

\subsection{Strip cast Al 3003 합금의 미세조직 및 상분 석 결과}

Strip casting 공정으로 제조된 Al 3003 합금의 ICP 분 


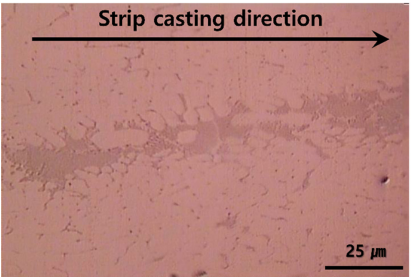

(a)

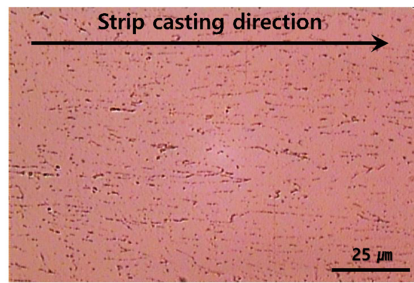

(b)
Fig. 1. (a) Optical microscope (OM) images of initial microstructures in $\mathrm{Al} 3003$ alloys manufactured by strip casting process; before heat-treatment $(\mathrm{F})$ and $(\mathrm{b})$ after heat-treatment $(\mathrm{O})$.

석 결과를 표 1 에 제시하였다. $1.15 \mathrm{wt} \% \mathrm{Mn}$ 과 함께 $\mathrm{Fe}$, $\mathrm{Si}, \mathrm{Cu}$ 원소들이 소량 포함되어 있으며 대체적으로 일반 $\mathrm{Al} 3003$ 합금 조성에 준하는 결과를 보였다. 그러나 $\mathrm{Si}$ 함량의 경우 $\mathrm{Al} 3003$ 합금 규격 $(0.600 \mathrm{wt} \% \mathrm{Si})$ 에 비해 낮은 값 $(0.136 \mathrm{wt} \% \mathrm{Si})$ 을 보였다.

Strip cast $\mathrm{Al} 3003$ 합금의 초기 미세조직 관찰결과를 그 림 1 에 나타냈다. 열처리 전 $\mathrm{F}$ 소재는 strip 중앙부에 회색 의 석출상들이 strip casting 방향으로 뭉쳐진 띠 형태를 이 루고 있었다. 그러나 열처리를 수행한 $\mathrm{O}$ 소재의 경우 $\mathrm{F}$ 소 재와 다르게 이 석출상들이 고르게 분산되어 분포하였다.

그림 2는 polarized light microscopy(PLM) 관찰 결과 이다. 사진에서 알 수 있듯 열 처리 유무에 상관없이 $\mathrm{F}$, $\mathrm{O}$ 두 소재 모두 globular 형상의 급랭 응고 조직이 관찰 되었다. 상기 독특한 미세조직은 일반 $\mathrm{DC}$ 공정으로 제조 된 $\mathrm{Al}$ 합금에서 나타나지 않는 것이다. 이러한 급냉 응고 조직은 strip casting 공정 특성상 용탕에서 바로 판재로 제조되면서 부여되는 빠른 냉각 속도에 의해 생길 수 있다 고 보고된 바 있다 $[16,17]$. 여기서 급냉 응고 조직이 $\mathrm{O}$ 열처리 후에도 거시적으로는 사라지지 않고 결정립 내부에 서 여전히 존재한다는 점에 주목할 만하다. 그러나 열처리 후의 급랭 응고 조직들은 상대적으로 다소 조대해졌으며 희미하게 나타났다.

$\mathrm{F}$ 와 $\mathrm{O}$ 소재의 $\mathrm{XRD}$ 상 분석 결과를 그림 3에 제시하 였다. $\mathrm{F}, \mathrm{O}$ 두 소재 모두 $\mathrm{Al}$ 기지, $\mathrm{Al}_{6}(\mathrm{Mn}, \mathrm{Fe})$ 그리고 $\alpha(\mathrm{AlMnFeSi})$ 상으로 구성되어 있었다. 일반적으로

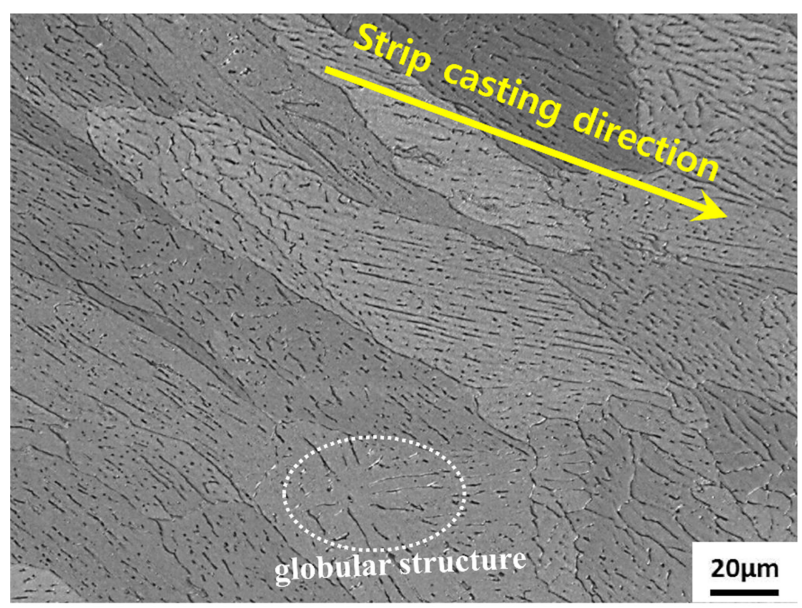

(a)

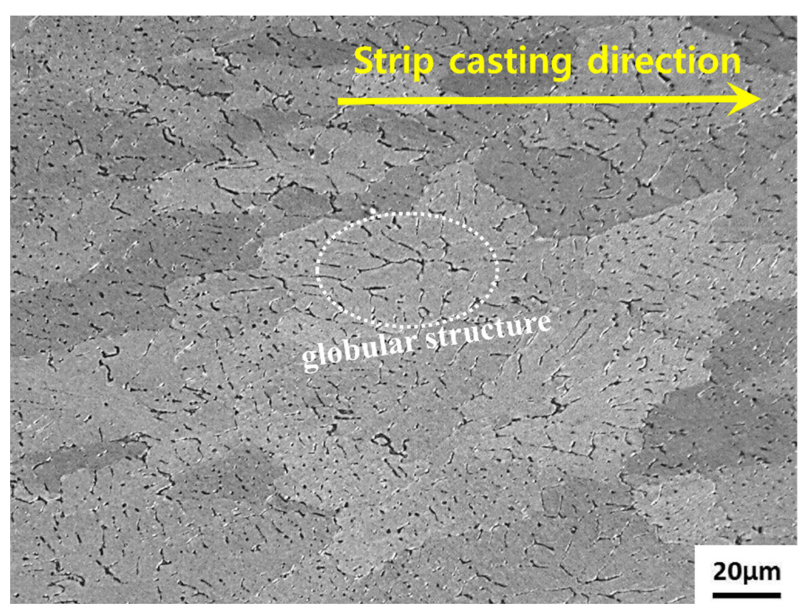

(b)

Fig. 2. (a) Polarized light microscopy (PLM) images of initial microstructures before heat-treatment $(\mathrm{F})$ and (b) after heattreatment (O) in strip cast $\mathrm{Al} 3003$ alloys.

$\mathrm{Al}_{6}(\mathrm{Mn}, \mathrm{Fe})$ 상 및 $\alpha(\mathrm{AlMnFeSi})$ 상은 $\mathrm{Al}-\mathrm{Mn}$ 계 합금에 서 강화상 역할을 수행한다고 알려져 있다. 이러한 강화상 들의 XRD 피크 강도(intensity) 비교에서, 열처리를 수행 함에 따라 $\mathrm{Al}_{6}(\mathrm{Mn}, \mathrm{Fe})$ 상은 피크 강도가 커지는 반면 $\alpha(\mathrm{AlMnFeSi})$ 상은 감소함을 알 수 있었다.

Strip 중앙부 영역을 중심으로 한 EPMA 원소 분석 결

Table 1 Chemical compositions of strip cast Al 3003 alloy used in this study (in wt\%).

\begin{tabular}{cccccccccc}
\hline & $\mathrm{Al}$ & $\mathrm{Si}$ & $\mathrm{Mn}$ & $\mathrm{Fe}$ & $\mathrm{Cu}$ & $\mathrm{Mg}$ & $\mathrm{Zn}$ & $\mathrm{Ti}$ \\
\hline $\begin{array}{c}\text { Strip casting } \\
\text { Al 3003 }\end{array}$ & Bal. & 0.136 & 1.14 & 0.53 & 0.16 & 0.001 & 0.003 & 0.018 \\
\hline $\begin{array}{c}\text { Standard } \\
\text { Al 3003 }\end{array}$ & Bal. & $<0.6$ & $1 \sim 1.5$ & $<0.7$ & $<0.2$ & 0.001 & $<0.1$ & 0.02 \\
\hline
\end{tabular}




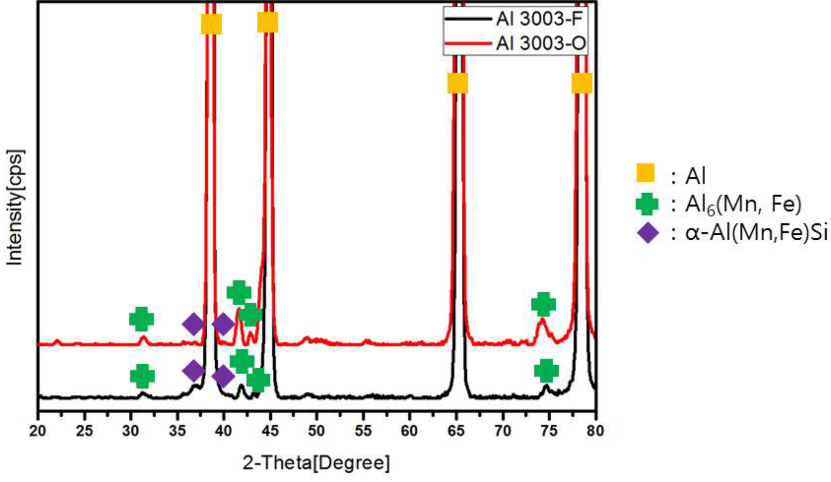

Fig. 3. XRD analysis results of strip cast $\mathrm{Al} 3003$ alloys.

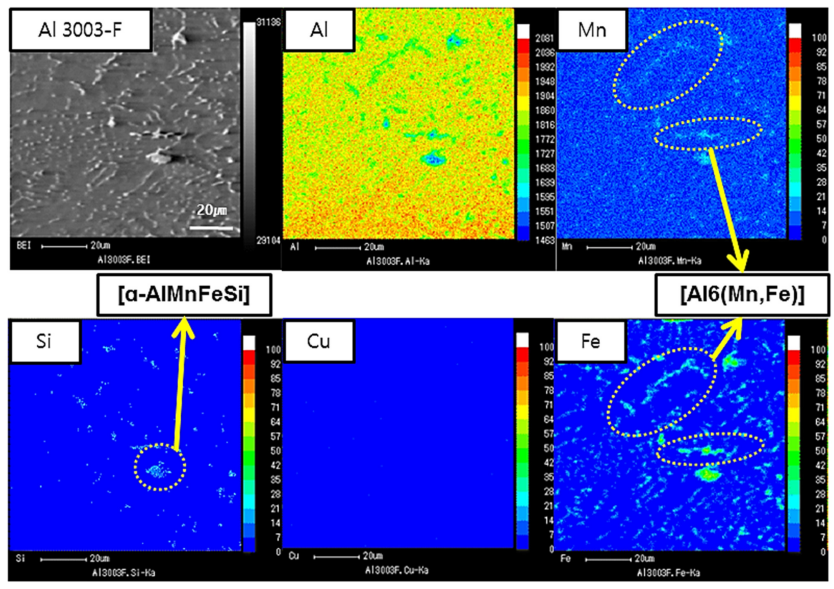

(a)
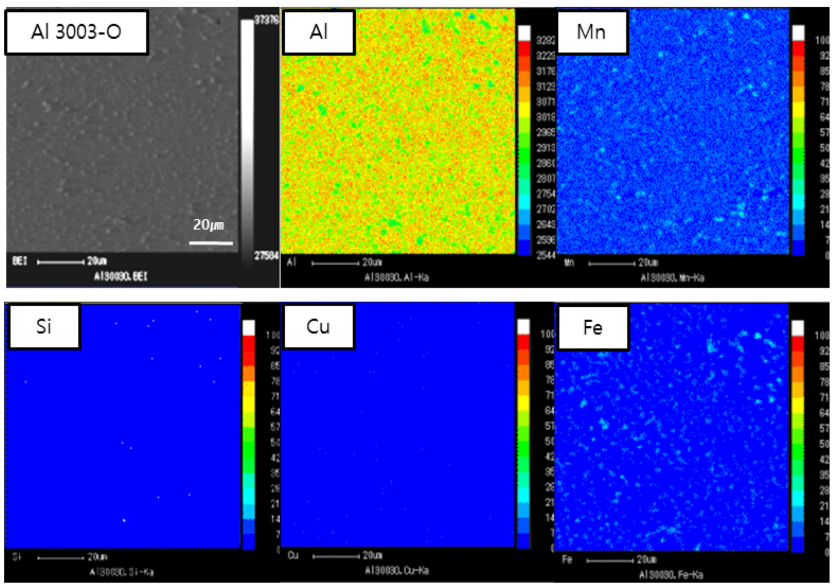

(b)

Fig. 4. (a) EPMA analysis results of initial microstructure before heat-treatment $(\mathrm{F})$ and $(\mathrm{b})$ after heat-treatment $(\mathrm{O})$ in strip cast $\mathrm{Al}$ 3003 alloys.

과를 그림 4에 제시하였다. 그 결과, 열처리 전 $\mathrm{F}$ 소재에 서 $\mathrm{Mn}, \mathrm{Fe}, \mathrm{Si}$ 성분을 포함하는 상들이 뭉쳐있는 것으로 나타났다. 그러나 $\mathrm{O}$ 열처리 후에는 뭉쳐져 있던 $\mathrm{Mn}, \mathrm{Fe}$,

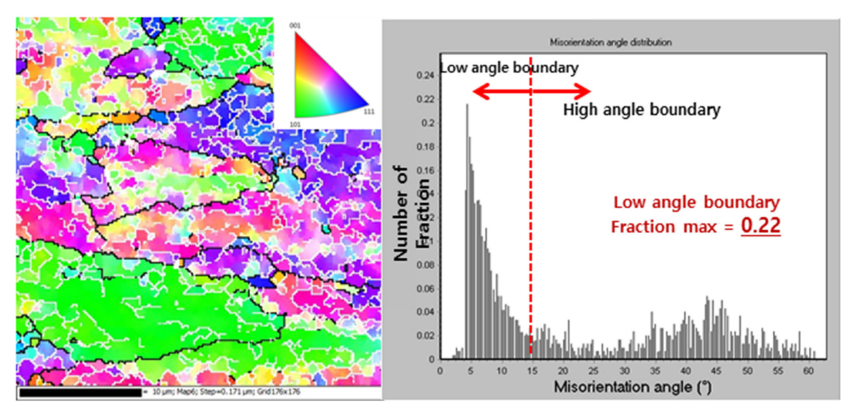

(a)

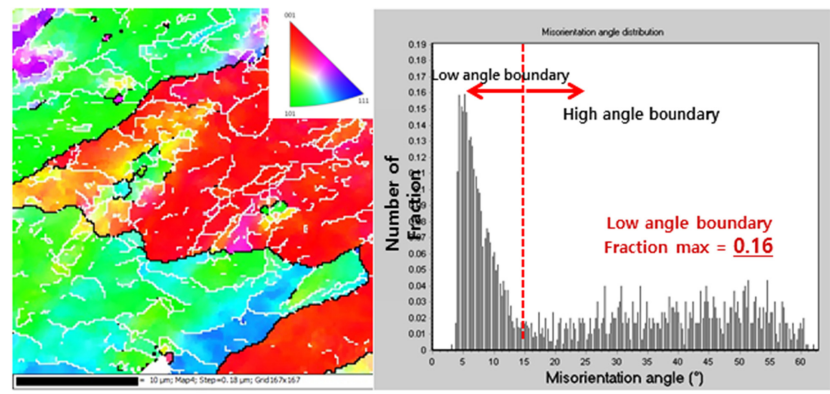

(b)

Fig. 5. (a) Inverse pole figure (IPF) map of strip cast Al $3003 \mathrm{~F}$ alloy with corresponding selected area legends (misorientation) and (b) IPF map with legends of strip cast Al $3003 \mathrm{O}$ alloy.

$\mathrm{Si}$ 상들이 전반적으로 넓고 고르게 분포하였다. 즉 열처리 를 수행함에 따라 strip 중앙부에 뭉쳐 있던 석출상들 $\left(\mathrm{Al}_{6}(\mathrm{Mn}, \mathrm{Fe}), \alpha(\mathrm{AlMnFeSi})\right)$ 이 $\mathrm{Al}$ 기지에 고루 분산됨을 다시 한번 확인할 수 있었다.

그림 5 는 열처리 전 $\mathrm{F}$ 소재와 열처리 후 $\mathrm{O}$ 소재의 $\mathrm{EBSD}$ (electron back scatter diffraction) 분석 결과를 나 타낸 것이다. IPF (inverse pole figure) map 결과에서 알 수 있듯이, 결정립 내부에서 결정 방위에 따라 여러 종류 의 색들이 다양하게 나타나고 있다 [18]. 열처리 전 $\mathrm{F}$ 소 재에 비해 열처리 후 $\mathrm{O}$ 소재의 결정립 내부 색 (color)들 이 상대적으로 유사하게 변한 것을 알 수 있었다. 또한 결 정립 내부의 IPF map에서 결정 방향이 조금씩 뒤틀어지는 경계선을 흰색 선(low angle boundary, $3 \sim 15^{\circ}$ 각)으로 결 정 방향이 크게(완전히) 뒤틀어지는 경계선을 검은색 선 (high angle boundary, $15 \sim 180^{\circ}$ 각)으로 나타냈다. 이를 바탕으로 그림 $5(\mathrm{~b}, \mathrm{~d})$ 에 두 소재의 misorientation angle 결과를 도시하였다. 여기에서 $\mathrm{O}$ 소재의 흰색 선(low angle boundary)은 $\mathrm{F}$ 소재에 비해 확연히 감소한 결과(a,c)를 볼 수 있으며, misorientation angle 분율 결과에서도 $\mathrm{F}(\max$ 약 0.22$)$ 에 비해 감소 $(\max$ 약 0.16$)$ 하는 것을 알 수 있었 다 (그림 5(b,d)). 일반적으로 low angle boundary의 분율 은 전위 밀도와 관계가 있다. 즉 초기 $\mathrm{F}$ 소재에서 존재하 


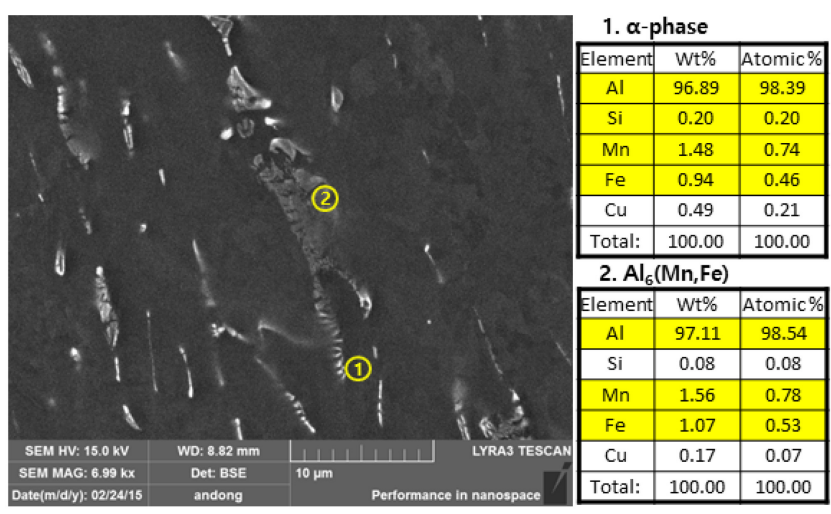

(a)

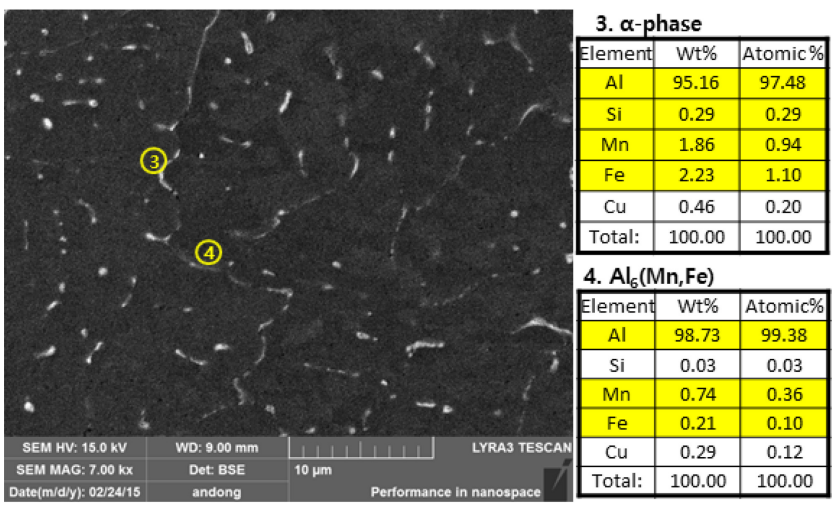

(b)

Fig. 6. (a) FE-SEM observation results of initial microstructure before heat-treatment $(\mathrm{F})$ and $(\mathrm{b})$ after heat-treatment $(\mathrm{O})$ in strip cast Al 3003 alloys.

던 전위들 및 low angle boundary들이 $\mathrm{O}$ 열처리로 의해 감소되며 그 결과 $\mathrm{Al}$ 기지의 연화가 일어나는 것을 유추 할 수 있었다.

그림 6에 열처리 전, 후의 $\mathrm{FE}-\mathrm{SEM}(\mathrm{BSE}$ mode)/EDS 분석 결과를 나타냈다. D.T.L. Alexander 등 [11]은 EDS 분석 결과와 더불어 $\mathrm{BSE}$ 모드의 명암 대비 차이로 석출 상들을 구분할 수 있다고 제시하였다. 본 연구에서도 상기 분석법을 이용하여 $\mathrm{EDS}$ 결과를 바탕으로 $\mathrm{F}$ 소재의 이미 지에서 짙은 회색을 $\mathrm{Al}$ 기지로, 옅은 회색을 $\mathrm{Al}_{6}(\mathrm{Mn}, \mathrm{Fe})$ 상으로 그리고 흰색을 $\alpha(\mathrm{AlMnFeSi})$ 상으로 유추할 수 있 었다. 또한 열처리 전 $\mathrm{F}$ 소재의 $\mathrm{FE}-\mathrm{SEM}$ 미세조직 관찰 결과에서는 $\mathrm{Al}_{6}(\mathrm{Mn}, \mathrm{Fe})$ 상 표면에 $\alpha(\mathrm{AlMnFeSi})$ 상이 형 성되어 있고 두 상이 혼재되어 있는 특징을 도출할 수 있 었다. 그러나 열처리 이후에는 이 혼재된 상들이 미세하고 고르게 분산되어 있었으며, 이는 앞선 EPMA 원소 분석 결과(그림 4)와도 잘 상응하는 것이다.

그림 7 에 나타낸 TEM 관찰 결과에서, FE-SEM 미세 조직과 마찬가지로 $\mathrm{O}$ 열처리 이후 혼재되어 있던
$\mathrm{Al}_{6}(\mathrm{Mn}, \mathrm{Fe})$ 상과 $\alpha(\mathrm{AlMnFeSi})$ 상이 분리되고 미세하고 고르게 분포하는 것을 알 수 있었다. 뿐만 아니라 FE$\mathrm{SEM}$ 수준에서 관찰하지 못한 $200 \mathrm{~nm}$ 수준의 미세한 $\alpha(\mathrm{AlMnFeSi})$ 상들이 TEM 분석에서 추가로 확인되었다. $\mathrm{V}$. Hansen 등 [10]은 $\mathrm{Al}-\mathrm{Mn}$ 계 합금에서 $\mathrm{Si}$ 함량이 낮 은 경우 열처리 후 $\alpha(\mathrm{AlMnFeSi})$ 상의 크기가 $100 \sim 500$ $\mathrm{nm}$ 수준으로 미세해질 수 있다고 보고하였다.

열처리 후 상 분포 및 크기 등의 변화 이외에 강화상의 분율의 변화도 중요한 미세조직학적 인자이다. $\mathrm{O}$ 열처리 이후 변화하는 $\alpha(\mathrm{AlMnFeSi})$ 상 및 $\mathrm{Al}_{6}(\mathrm{Mn}, \mathrm{Fe})$ 상의 상 분율을 분석하여 그림 8 및 표 2에 제시하였다. 여기에서 FE-SEM 미세조직 이미지 및 Image analyze program을 통해 분석한 정량적인 상 분율을 함께 제시하였다. 열처리 이후 $\alpha(\mathrm{AlMnFeSi})$ 상의 분율은 감소하고 $\mathrm{Al}_{6}(\mathrm{Mn}, \mathrm{Fe})$ 상 분율은 다소 증가함을 알 수 있었다. 상기 결과는 앞서 $\mathrm{XRD}$ 분석(피크 강도) 결과를 통해 유추한 상 분율 결과 (그림 3)와도 일치하는 것이다. 이와 관련하여 그림 8(b) Factsage phase simulation program을 이용하 상 분석 해 석 결과에서도 온도가 증가함에 따라 $\alpha(\mathrm{AlMnFeSi})$ 상 분 율은 감소하며 $\mathrm{Al}_{6}(\mathrm{Mn}, \mathrm{Fe})$ 상 분율이 증가하는 동일한 경 향을 얻을 수 있었다.

Y. F. Cheng 등 [8-10]에 의하면 Al-Mn계 합금에서는 $\mathrm{Si}$ 함량이 강화상 형성에 주요하게 영향을 미친다고 보고 하였다. 즉, $\mathrm{Si}$ 함량에 따라 고온 안정상이 다르게 생성될 수 있다고 주장하였다. 여기서 $\mathrm{Si}$ 함량이 높을수록 $\alpha(\mathrm{AlMnFeSi})$ 상이, $\mathrm{Si}$ 함량이 낮을수록 $\mathrm{Al}_{6}(\mathrm{Mn}, \mathrm{Fe})$ 상이 더 안정한 고온상이라고 제시하였다. 본 연구에서 사용된 소 재의 $\mathrm{Si}$ 함량은 $0.136 \mathrm{wt} \%$ 로(표 1) 표준 $\mathrm{Al} 3003$ 합금의 $\mathrm{Si}$ 함량 $(0.600 \mathrm{wt} \%)$ 보다 소폭 낮기 때문에 $\mathrm{Al}_{6}(\mathrm{Mn}, \mathrm{Fe})$ 상이 고온에서 더 안정할 것으로 사료된다. 관련하여 $\mathrm{Si}$ 함량 차 이에 의해 $\alpha(\mathrm{AlMnFeSi})$ 상 분율의 증가와 감소 관찰 결과 가 보고된 바 있다 $[19,20]$. 본 연구에서 열처리 후 주 강 화상인 $\alpha(\mathrm{AlMnFeSi})$ 상의 경우 상 분율은 감소하지만 그 분포는 미세하고 고르게 분산되는 것을 알 수 있었다.

\subsection{Strip cast $\mathrm{Al} 3003$ ( $\mathrm{F}$ and $\mathrm{O}$ ) 합금의 인장 특성 및 변형 거동}

열처리 전, 후의 상온 인장 실험 결과를 그림 9에 나타 냈으며, 측정된 경도 및 상온 인장 물성을 표 3에 정리하 였다. 경도 값은 열처리 전 $59.7 \mathrm{Hv}$ 에서 열처리 후 53.4 $\mathrm{Hv}$ 로 $6.3 \mathrm{Hv}(10.6 \%)$ 감소하였고, 항복강도는 $124.8 \mathrm{MPa}$ 에서 $112.2 \mathrm{MPa}$ 로 $12.6 \mathrm{MPa}(10.1 \%)$ 감소하였다. 일반적 으로 어닐링 열처리 이후 항복 강도가 감소하는 것은 잘 

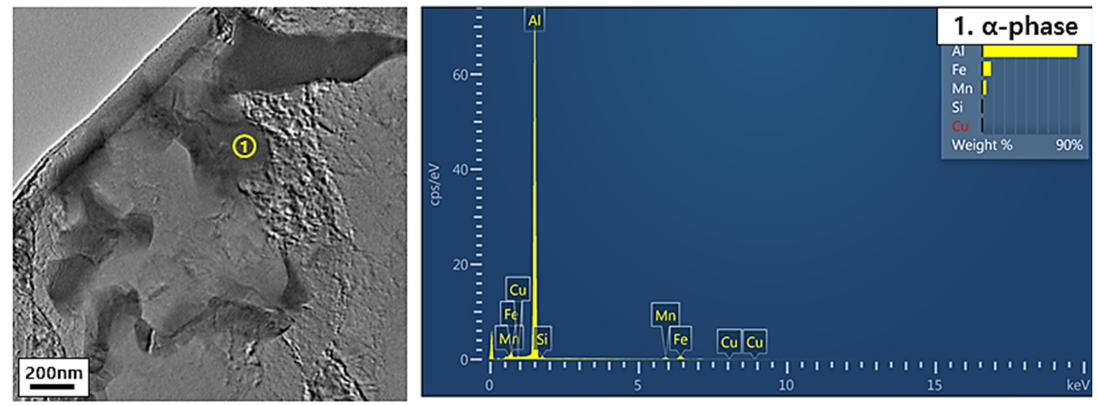

(a)
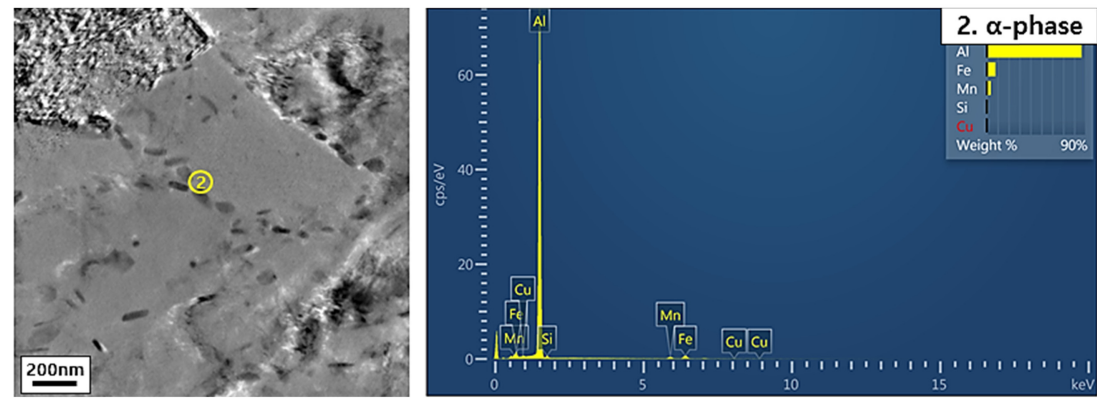

(b)

Fig. 7. (a) TEM observation and EDS analysis results of initial microstructure before heat-treatment (F) and (b) after heat-treatment (O) in strip cast Al 3003 alloys.

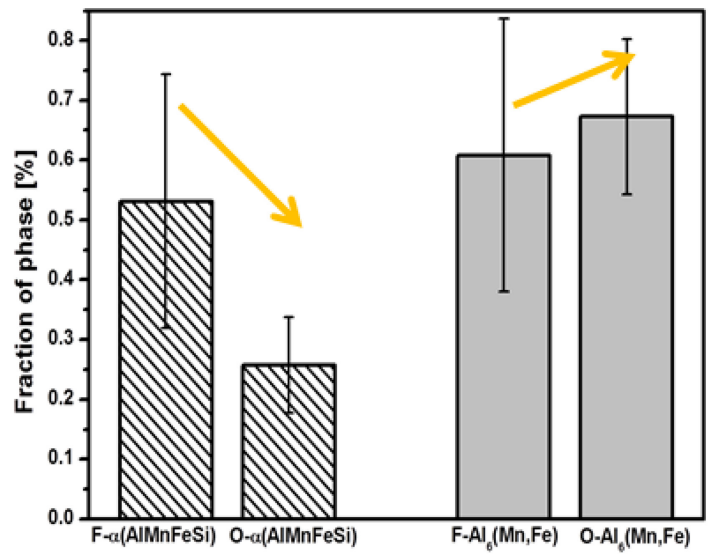

(a)

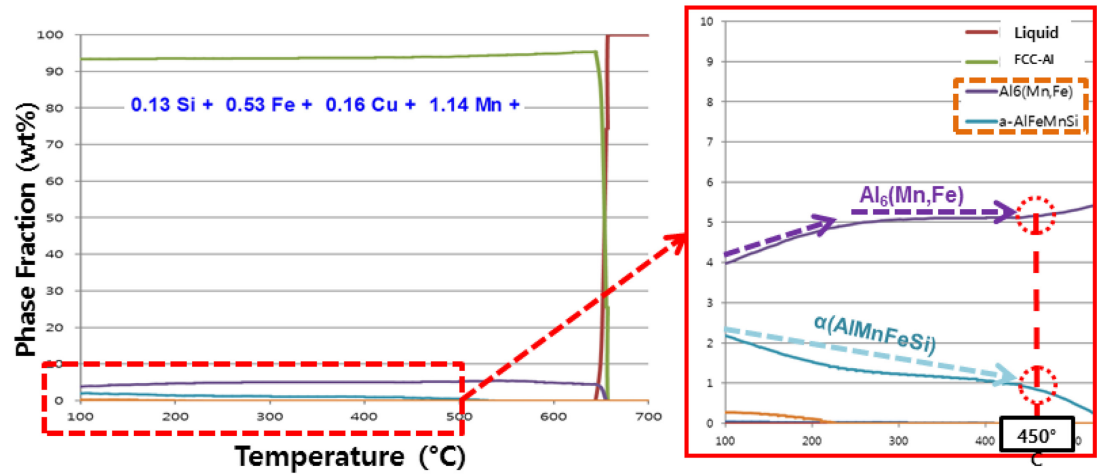

(b)

Fig. 8. (a) Comparison of phase fraction using FE-SEM observation results (b) and Factsage simulation of strip cast Al 3003 alloys. 
Table 2 Representative phase fraction of strip cast Al 3003 alloys.

\begin{tabular}{cccc}
\hline & $\begin{array}{c}\alpha-(\mathrm{AlMnFeSi}) \\
{[\%]}\end{array}$ & $\begin{array}{c}\mathrm{Al}_{6}(\mathrm{Mn}, \mathrm{Fe}) \\
{[\%]}\end{array}$ & Total [\%] \\
\hline $\mathrm{Al} 3003-\mathrm{F}$ & 0.531 & 0.608 & 1.139 \\
\hline $\mathrm{Al} 3003-\mathrm{O}$ & 0.257 & 0.673 & 0.93 \\
\hline
\end{tabular}

Table 3 Representative tensile properties of strip cast Al 3003 alloys.

\begin{tabular}{ccccc}
\hline & $\begin{array}{c}\text { Hardness } \\
{[\mathrm{HV}]}\end{array}$ & Y.S. [MPa] & $\begin{array}{c}\text { U.T.S. } \\
{[\mathrm{MPa}]}\end{array}$ & El. [\%] \\
\hline $\mathrm{Al} 3003-\mathrm{F}$ & 59.7 & 124.8 & 166.4 & 19.6 \\
\hline $\mathrm{Al} 3003-\mathrm{O}$ & 53.4 & 112.2 & 167.2 & 23.0 \\
\hline
\end{tabular}

알려져 있다. 이와 관련하여 V. Hansen et. al. [10]은 strip casting 공정으로 제조한 $\mathrm{Al} 3003$ 합금을 $400{ }^{\circ} \mathrm{C}$ 온 도에서 열처리할 경우 항복 강도를 조사하였으며 $\mathrm{Si}$ 함량 에 따라 강도 값이 변화함을 보고하였다. 여기에서 $\mathrm{Si}$ 함 량이 $0.240 \mathrm{wt} \% \mathrm{Si}$ 보다 낮은 경우 열처리 후 항복 강 도가 감소함을 제시하였으며, 이는 본 연구에서의 결과 $(0.136 \mathrm{wt} \% \mathrm{Si})$ 와 상응하는 것이다. 연신율의 경우 열처리 전 $19.6 \%$ ( $\mathrm{F}$ 소재), 열처리 후 $23.0 \%$ (O 소재)로 나타
났으며, 이는 열처리에 의한 기지 연화에 기인하는 것으로 판단된다. 한편 그림 9 의 결과에서 열처리 후 항복 강도는 감소하는 반면 가공 경화 거동이 더 크게 나타나 인장 강 도는 열처리 전과 유사한 특징을 나타냈다. 이러한 특징은 열처리 이후 미세하게 석출 분산된 강화상들에 기인하는 것으로 생각된다 [21,22]. 그림 $9(\mathrm{~b}, \mathrm{c})$ 에서 두 소재의 변형 률에 따른 가공 경화 지수(work hardening exponent)를 계산하여 도시하였다. $\mathrm{O}$ 열처리 합금에서 가공 경화지수 값이 $\sim 0.128$ 수준으로 얻어져 열처리 전 소재(F, 0.119 수준)에 비해 더 높은 값을 나타냈다. 즉 열처리 $(\mathrm{O})$ 소재 의 가공 경화 거동이 더 크게 나타남을 정량적으로 제시할 수 있었다.

두 소재의 인장 파단면 관찰 결과를 그림 10 에 제시하 였다. 두 소재 모두에서 연성 파괴일 때 나타나는 전형적 인 dimple들이 관찰되었다. 상기 dimple 들의 크기를 측 정하였으며, 그 결과 열처리 전 평균 $~ 4.35 \mu \mathrm{m}(\mathrm{F}$ 소재 $)$ 에서 열처리 후 평균 $~ 3.6 \mu \mathrm{m}(\mathrm{O}$ 소재 $)$ 로 미세해진 것을 알 수 있었다. 이는 열처리 전, 후 초기 미세조직 결과에 서 언급한 바와 같이 열처리에 따른 강화 상들의 미세화 에 의한 것으로 판단된다. 한편 두 소재의 인장 파단면에

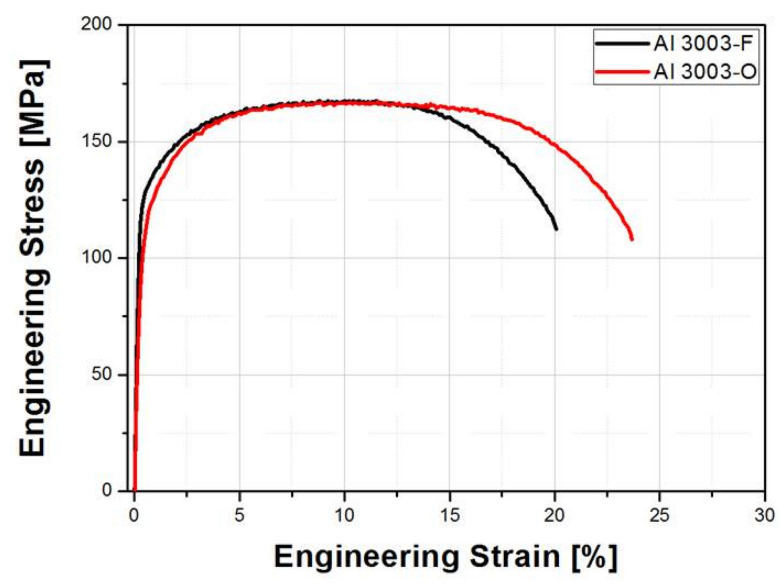

(a)

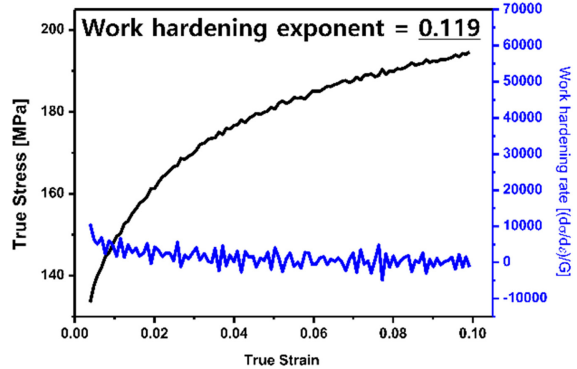

(b)

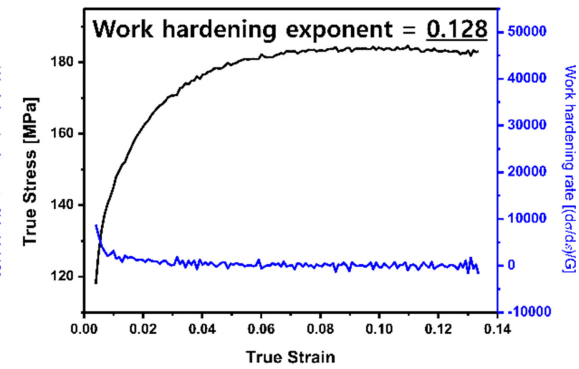

(c)

Fig. 9 (a) Comparison of tensile properties of strip cast Al 3003 alloys and (b) work hardening exponent analysis results of F alloy and (c) O alloy. 

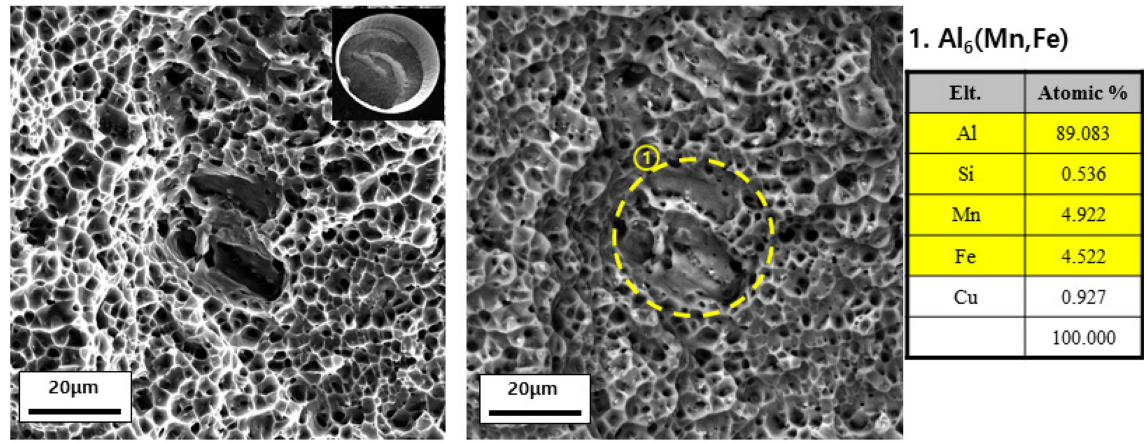

(a)
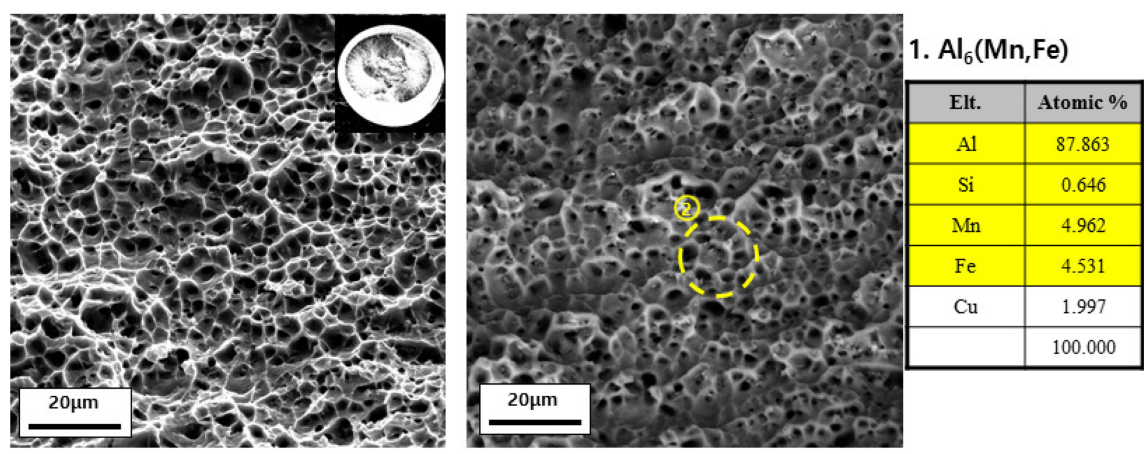

(b)

Fig. 10. (a) SEM observation results of tensile fractography of $F$ alloy with back-scatter detector (BSE) image and (b) those of O alloy.

서도 관찰되는 강화상의 분포 특징에서도 차이를 보였다. 열처리 전 $(\mathrm{F})$ 소재는 dimple들 사이에 강화상들이 뭉쳐 있는 반면, 열처리 후 $(\mathrm{O})$ 소재의 강화상들은 파단면에서 뭉 침 현상 없이 고루 분포하였다. 이처럼 열처리에 의한 $\mathrm{Al}_{6}(\mathrm{Mn}, \mathrm{Fe})$ 강화상 분율 증가 및 주 강화상들 $\left(\mathrm{Al}_{6}(\mathrm{Mn}, \mathrm{Fe})\right.$, $\alpha(\mathrm{AlMnFeSi}))$ 의 미세화는 변형이 진행됨에 따라 더 많은 가공 경화를 유도하고 결과적으로 최대 인장 강도(UTS)의 증가를 가져오는 것으로 사료된다.

\subsection{Strip cast Al 3003 합금의 고주기 피로 특성} 및 피로 변형 거동

Strip cast Al 3003 합금 열처리 전(F), 후(O) 소재들의 고주기 피로 특성 결과 (S-N curve)를 그림 11에 나타냈 다. 열처리 전 소재의 피로한도는 $145 \mathrm{MPa}$, 열처리 후 소 재는 $135 \mathrm{MPa}$ 로 측정되었으며, 모든 피로 응력 (fatigue stress) 조건에서 열처리 전 소재가 우수한 피로 수명을 보 였다. 일반적으로 피로 저항성은 항복 강도와 비례하여 항 복강도가 우수한 $\mathrm{F}$ 소재가 $\mathrm{O}$ 소재에 비해 우수한 피로 특성을 나타낸 것으로 생각된다. 이는 인장 특성에서 확인 된 것과 같이 열처리 후 소재의 $\mathrm{Al}$ 기지 연화에 기인하는

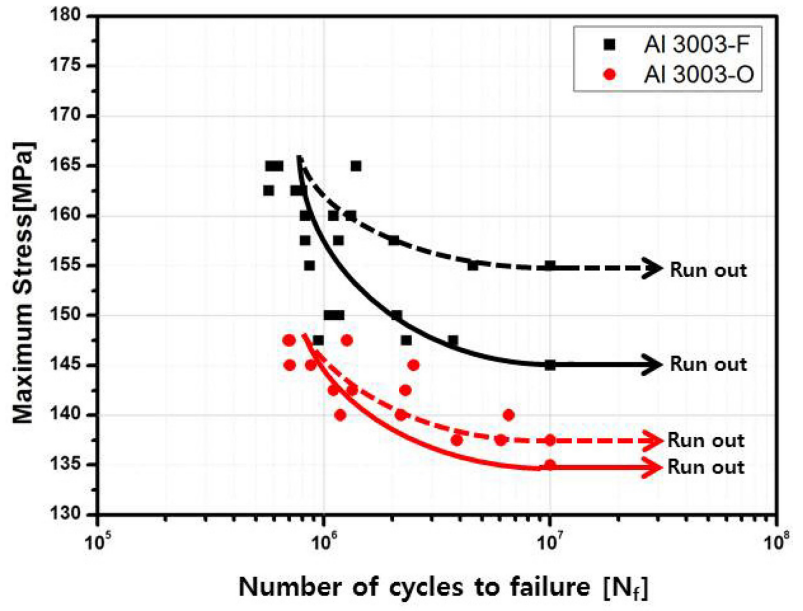

Fig. 11. High-cycle fatigue properties (S-N curves) of strip cast $\mathrm{Al}$ 3003 alloys; $\mathrm{F}$ alloy (black line) and $\mathrm{O}$ alloy (red line).

것으로 설명될 수 있다 [23]. 또한 S-N 곡선들을 보다 상 세히 살펴보면 두 소재 모두 각각 2개의 run out 들이 나 타나는 것에 주목할 만하다 (점선과 실선). 그림 11에 나 타난 2개의 run out은 피로 수명(fatigue life)이 불균일 하다는 것을 의미한다. 즉, 점선으로 나타낸 $\mathrm{S}-\mathrm{N}$ 곡선은 

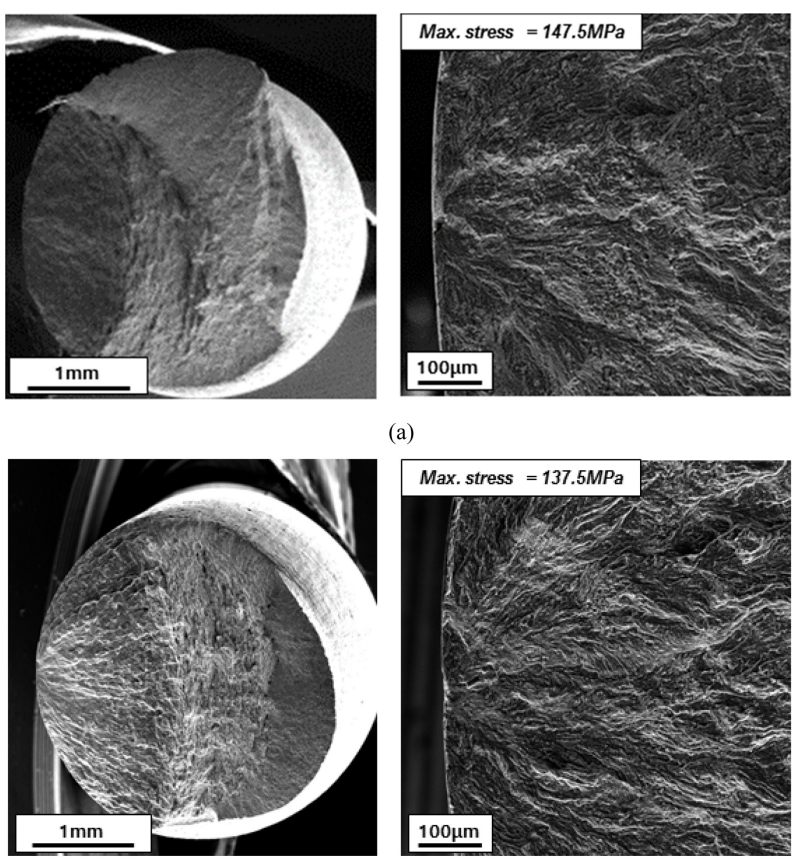

(a)

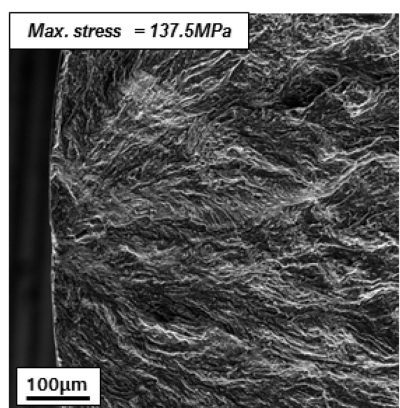

(b)

Fig. 12. SEM observation results of high-cycle fatigue fractography at fatigue crack initiation area of strip cast Al 3003 alloys; (a) F alloy and (b) $\mathrm{O}$ alloy.
동일 응력당 우수한 피로 수명을 보인 결과이며 실선으로 나타낸 곡선은 동일 응력당 낮은 피로 수명을 제시한 결과 이다. $\mathrm{F}$ 소재의 run out 들은 $155 \mathrm{MPa}, 145 \mathrm{MPa}$ 의 응력 에서 확인되었다. $\mathrm{O}$ 소재의 경우 run out 들은 137.5 $\mathrm{MPa}, 135 \mathrm{MPa}$ 의 응력에서 나타났으며, 열처리 후 run out 폭이 확연히 줄어든 것을 알 수 있었다. 이와 함께 피 로 수명의 변동 폭(deviation)은 $\mathrm{O}$ 소재가 $\mathrm{F}$ 소재에 비해 좁은 것으로 나타나 피로 수명에 대한 신뢰성이 높아졌음 을 알 수 있었다.

두 소재 모두 피로 파면 시작점에서 기공 및 개재물 (inclusion)과 같은 결함(defects)들은 관찰되지 않았다 (그 림 12). 그러나 거시적인 피로 균열 전파(fatigue crack propagation) 영역에서 $\mathrm{F}$ 소재와 $\mathrm{O}$ 소재는 서로 다른 피로 파면 특징을 나타냈다. 즉 $\mathrm{F}$ 소재는 $\mathrm{O}$ 소재에 비해 상대 적으로 조대하고 불균일한 피로 파면을 보였다. 이는 $\mathrm{F}$ 소 재 내부의 중앙부에서 존재하는 조대한 석출상들의 영향으 로 생각된다.

고 배율로 피로 파단 시편들의 피로 균열 전파 영역을 관찰하였으며, 이를 그림 13 에 제시하였다. 먼저 그림 13(a)를 살펴보면, $\mathrm{F}$ 소재는 조대한 피로 균열 그리고 조밀
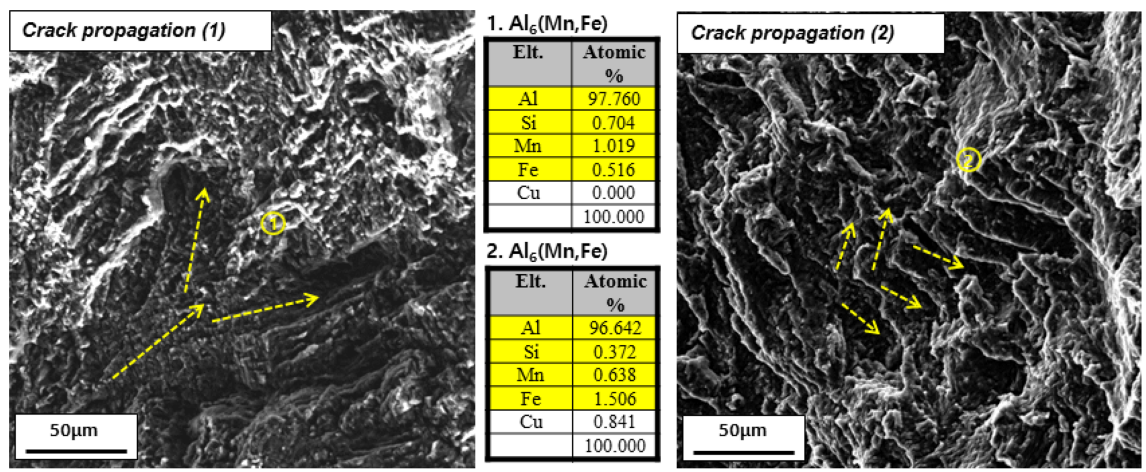

(a)
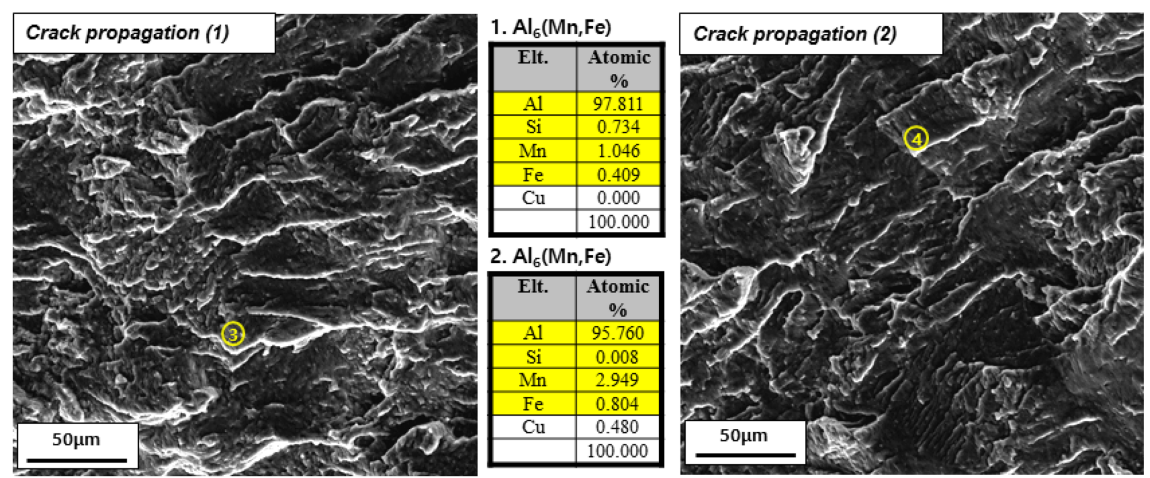

(b)

Fig. 13. High magnification SEM observation results of high-cycle fatigue fractography at fatigue crack propagation area of strip cast $\mathrm{Al}$ 3003 alloys; (a) F alloy and (b) $\mathrm{O}$ alloy. 
하고 균일한 피로 균열 두 가지의 피로 파면 영역들이 관찰 되었다 (노란색 점선). 일반적으로 반복 응력이 가해지는 고 주기 피로 시험의 경우 불균일하게 뭉쳐있는 상들은 피로 균열을 촉진시킬 수 있다. $\mathrm{F}$ 소재에 나타난 조대한 피로 파 면은 불균일하게 혼재된 $\mathrm{Al}_{6}(\mathrm{Mn}, \mathrm{Fe})$ 상 $\alpha(\mathrm{AlMnFeSi})$ 상에 의해 피로 균열 전파 저항이 균일하게 이루어지지 못하였 기 때문으로 생각된다 [24,25]. 이에 반해 $\mathrm{O}$ 소재는 피로 균열 전파 거동이 모두 조밀하고 균일한 것으로 관찰되었 다 (그림 13(b)). 즉, $\mathrm{O}$ 소재는 $\mathrm{F}$ 소재와 달리 두 가지 형태의 피로 파면이 아니며, 모든 영역이 균일한 피로 파 면으로 나타났다. 이는 열처리 이후 강화상들의 균일한 분 포 및 미세화 (약 $200 \mathrm{~nm}$ 수준) 때문으로 해석될 수 있다. 강화상들의 균일한 분포는 피로 균열 전파 저항성을 높이 고 피로 파괴(fatigue fracture)를 더 효과적으로 지연시킨 다 [26,27]. 그 결과로, 열처리 후(O) 소재는 열처리 전(F) 소재에 비해 run out 폭 및 피로 수명 변동 폭을 더 좁 게 나타내는 것으로 판단된다. 일반적으로 피로 수명의 변 동 폭은 피로 수명에 대한 신뢰성과 연관된다. 또한 고주 기 피로에서 피로 수명에 대한 신뢰성은 매우 중요하다. 결과적으로 $\mathrm{O}$ 소재는 열처리 이후 $\mathrm{Al}$ 기지의 연화로 인해 고주기 피로 특성은 다소 낮아졌지만 피로 응력에 대한 신 뢰도가 높아지는 것을 확인할 수 있었다. 즉 strip casting 공정으로 제조된 $\mathrm{Al} 3003$ 합금의 경우 후 열처리를 통해 불균일한 상들의 분포를 제어하고 기계적 특성을 개선시킬 수 있었다.

\section{4. 결 론}

본 연구에서는 strip casting 공정으로 제조된 Al 3003 합금의 미세조직, 인장 및 고주기 피로 특성에 미치는 후 열처리의 영향에 대해 조사하였으며 다음과 같은 결론을 얻을 수 있었다.

열처리 전, 후의 XRD 및 $\mathrm{FE}-\mathrm{SEM}$ 분석 결과, $\mathrm{Al}$ 기 지에 $\alpha(\mathrm{AlMnFeSi})$ 상 및 $\mathrm{Al}_{6}(\mathrm{Mn}, \mathrm{Fe})$ 상들이 존재하였다. 또한 열처리 전 스트립 내부 중앙부에 불균일하고 뭉쳐져 있던 $\alpha(\mathrm{AlMnFeSi})$ 상 및 $\mathrm{Al}_{6}(\mathrm{Mn}, \mathrm{Fe})$ 상들은 열처리 후 균일하고 미세하게 변화하였다. 또한 $\mathrm{EBSD}$ 분석결과를 통 하여 열처리 후 strip casting 공정에 기인하여 높은 전위 밀도가 낮아졌음을 유추해볼 수 있었다.

Factsage program 및 FE-SEM 이미지 분석을 이용하여 열처리 후 $\alpha(\mathrm{AlMnFeSi})$ 상 분율은 감소한 반면, $\mathrm{Al}_{6}(\mathrm{Mn}, \mathrm{Fe})$ 상 분율은 증가하는 것을 확인하였다. 또한 $\mathrm{TEM}$ 관찰 결과 에서도 열처리 후 $\alpha(\mathrm{AlMnFeSi})$ 상은 $200 \mathrm{~nm}$ 수준으로 미세
해지는 것을 알 수 있었다. 이는 혼재되어 있던 $\mathrm{Al}_{6}(\mathrm{Mn}, \mathrm{Fe})$ 상과 $\alpha(\mathrm{AlMnFeSi})$ 상이 분리, 재석출되었기 때문으로 판단된다.

인장 시험 결과 열처리 전 소재 $(\mathrm{F})$ 의 경우 $\mathrm{YS}$ : 124.8 $\mathrm{MPa}, \mathrm{UTS}: 166.4 \mathrm{MPa}$ 그리고 열처리 후 소재 $(\mathrm{O})$ 의 경우 YS: 112.2 MPa, UTS: 167.2 MPa로 얻어져, 열처리 후 소재가 항복 강도(YS)는 낮지만 최대 인장 강도(UTS)는 유사하거나 조금 높은 값을 가졌다. 이는 열처리에 의한 $\mathrm{Al}$ 기지의 연화에 기인하여 항복 강도는 감소하였지만 미 세하고 고른 분포의 강화상들에 의해 UTS가 증가한 것으 로 해석되었다. 연신율은 $19.6 \%$ ( $\mathrm{F}$ 소재), $23.0 \%$ (O 소 재)로 $\mathrm{O}$ 소재의 연신율이 더 높게 나타났다.

고주기 피로 시험 결과 $\mathrm{F}$ 소재가 $\mathrm{O}$ 소제에 비해 모든 응력 조건에서 우수한 피로 특성을 나타냈다. 그러나 $\mathrm{O}$ 소 재는 $\mathrm{F}$ 소재에 비해 피로 수명 변동 폭이 좁아져 피로 물 성의 신뢰성이 향상되었다. $\mathrm{O}$ 소재에서는 $\mathrm{F}$ 소재와 달리 균일하고 고른 피로 파면이 관찰되었다. 즉 열처리에 의한 미세하고 균일한 상 분포는 피로 수명 변동 폭을 낮추며, 피로 수명에 대한 신뢰성을 높이는 것을 알 수 있었다.

\section{REFERENCES}

1. Z. P. Xing, S. B. Kang, and H. W. Kim, J. Mater. Sci. 39, 1259 (2004).

2. J. R. Davis, ASM International, Materials Park, pp. 33, Ohio (1993).

3. Y. S. Park, S. B. Lee, and N. J. Kim, Mater. Trans. 44, 2617 (2003).

4. T. Haga, K. Tkahashi, M. Ikawaand, and H. Watari, J. Mater. Process. Technol. 153-154, 42 (2004).

5. J. P. Martins, A. L. M. Carvalho, and A. F. Padilha, J. Mater. Sci. 44, 2966 (2009).

6. N. Sum, B. R. Patterson, J. P. Suni, E. A. Simielli, H. Weiland, and L. F. Allard, Mater. Sci. Eng. A 416, 32 (2006).

7. Y. J. Li and L. Arnberg, Acta Mater. 51, 3415 (2003).

8. V. Hansen, J. Gjonnes, and B. Andersson, J. Mater. Sci. Let. 8, 823 (1989).

9. Y. F Cheng, V. Hansen, J. Gjonnes, and L. R. Wallenberg, J. Mater. Res. 7, 3235 (1992).

10. V. Hanse, B. Andersson, J. E. Tibballs, and J. Gjonnes, Metall. Mater. Trans. B 26B, 839 (1995).

11. D. T. L. Alexander and A. L. Greer, Acta Mater. 50, 2571 (2002).

12. M. Warmuzek, G. Mró wak, and J. Sieniawski, J. Mater. 
Process. Technol. 157-158, 624 (2004).

13. G. S. Ham, K. J. Euh, Y. M. Rhyim, and K. A. Lee, Mater. Trans. 57, 78 (2016).

14. J. Y. Heo, M. S. Baek, K. J. Euh, and K. A. Lee, Met. Mater. Int. 24, 992 (2018).

15. Y. Birol, J. Alloy. Compd. 471, 122 (2009).

16. D. T. L. Alexander and A. L. Greer, Philos. Mag. 84, 3071 (2004).

17. A. Bahadur, J. Mater. Sci. 23, 48 (1988).

18. E. J. Jung and S. I. Yoo, J. Korean Ceram. Soc. 5, 54 (2002).

19. Y. J. Li, A. M. F. Muggerud, A. Olsen, and T. Furu, Acta Mater. 60, 1004 (2012).

20. G. S. Ham, K. J. Euh, Y. M. Kim, and K. A. Lee, Mater. Trans. 57, 78 (2016).
21. M. Jobba, R. K. Mishra, and M. Niewczas, Int. J. Plast. 65, 43 (2015).

22. R. Chen, Q. Xu, Z. Jia, and B. Liu, Mater. Des. 90, 1059 (2016).

23. J. C. Pang, S. X. Li, Z. G. Wang, and F. Zhang, Fatigue Fract. Eng. Mater. Struct. 37, 958 (2014).

24. M. J. Kim, K. Y. Kim, G. J. Euh, Y. M. Rhym, and K. A. Lee, Korean J. Met. Mater. 53, 169 (2015).

25. Y. K. Kim, M. J. Kim, Shae K. Kim, Y. O. Yoon, and K. A. Lee, Trans. Mater. Process. 26, 306 (2017)

26. F. Li, Z. Liu, W. Wu, P. Xia, P. Ying, Y. Zhou, W. Liu, L. Lu, and A. Wang, Mater. Sic. Eng. A 679, 204 (2017).

27. Z. Y. Li, X. L. Liu, G. Q. Wu, and Z. Huang, Met. Mater. Int. 25, 64 (2019). 